\title{
EVALUATION OF TACTICAL PLANNING MATURITY IN SUPPLY CHAINS OF MANUFACTURING COMPANIES
}

\author{
Dorota Szczakowska ${ }^{\bowtie}$ \\ Warsaw School of Economics, Poland
}

\begin{abstract}
This paper aims to propose and test a model facilitating assessment of tactical planning maturity in supply chains of manufacturing companies. The author proposes a model called Tactical Planning Maturity Model (TPMM). The model is created based on literature research, participant observations and data gathering conducted in two companies. The proposed framework combines both knowledge from supply chain integration and steps necessary to reach proficiency in sales and operation planning. The second step consists of choosing a case study method to verify model adequacy in two companies operating in central Poland. The findings illustrate the TPMM as a ready-to-use tool where the line to supply chain maturity is clearly drafted and results could be compared between production companies. This paper strengthens the link between practitioner and academic literature by providing empirical evidence of the benefits of tactical planning maturity model usage as well as its impact on further development of supply chains. This paper studied merely two companies and is not intended to be representative of outcomes for all companies looking to understand the complexity and maturity of their supply chains. Furthermore, the analyzed companies only reached level four in the maturity model; levels five and six were not observed. Further quantitative studies are required for testing the accuracy of the proposed model and potentially, qualitative studies could be undertaken in order to understand factors enabling the increase in maturity of tactical planning in the supply chains of manufacturing companies.
\end{abstract}

Key words: tactical planning maturity model, S\&OP maturity model, sales and operational planning maturity model, supply chain development, maturity model in supply chain

JEL codes: M10, M20, O21

\section{INTRODUCTION}

At present, it is believed that the turbulent environment and pace of changes limits the possibility of business planning. Meanwhile, research shows that the stronger the turbulence and major changes in operating conditions, the more attention should be given to planning and extending its horizon, because without it a company is unable to maintain its chosen course, influence its surroundings and pursue its interests. Komorowski in the book "Zarys budżetowania przedsiębiorstwa" ("Outline of company budgeting"), writes that "the essence of planning in an enterprise is the projection of its immediate or distant future. This is not about forecasting, but rather a realistic use of the potential of a given entity against the background of future predictions."

Komorowski determines planning as a conscious choice and an expression of the will to act in relation to the future [Komorowski 2015]. There are available studies confirming that correct implementation of the tactical planning process results in an increase of the effectiveness and efficiency of the supply chain functioning. For example, employees of the University of 
Lancaster report a $67 \%$ reduction in delivery time for new products; in another case study, a $30 \%$ reduction in the level of inventory and a $52 \%$ increase in the correctness of sales forecasts was indicated [Márcio et al., 2012]. AMR Research informs that correctly implemented demand-driven S\&OP can improve revenue from 2 to $5 \%$, reduce inventories by 7 to $15 \%$, and improve new product launch commercialization by $20 \%$ [Cecere et al. 2009].

Aberdeen Group also conducted multiple studies according to which, companies with mature S\&OP processes notice improvement of $2.7 \%$ in gross margin improvement, whereas companies with less advanced S\&OP processes demonstrate improvement of $1.3 \%$ in gross margin [Aberdeen 2011]. Cash-to Cash Cycle-Days are accordingly assessed for 44 days and 65 days for companies with less mature processes. Presented results also highlight improvement within areas of customer service level and average forecast accuracy at the product family level. Tinker informs that implementing or improving an S\&OP process can produce improvements of 5 to $25 \%$ in such areas as working capital reduction, reduction of obsolete inventory, transportation, production and material costs, time to market, and sales growth [Tinker 2010].

Additional research results reported by Tinker in 2017 inform about improvements in operational metrics such as: forecast error, inventory turns, on-timein-full, planning cycle time, supply performance related, distribution related, customer satisfaction. Additionally, the researchers agree that cross-functional planning processes can mitigate the negative effect of misaligned organizational structures and contradictory incentives schemes on firm performance. It is also concluded that internal alignment seems to facilitate supply chain integration with both suppliers and customers [Márcio et al. 2012]. From the other side there is confirmation of the positive impact of organizational integration on the level of the tactical planning process and its effectiveness [Swaim et al. 2016]. Researchers argue that companies investing in the integration process overcome competing companies because they have better-matched goals and business processes, which supports coordination and matching of cooperators [Swink et al. 2007]. Grimson and Pyke draw attention to the higher level of S\&OP integration where the goal is not only to communicate and coordinate plans among sales, operation and finance, but to work on developing the most profitable scenarios for the organization [Grimson and Pyke 2007].

Despite the above-mentioned voices that: 1) increase in S\&OP maturity, 2) supply chain integration, supports increase of company effectiveness and efficiency, research points out that the linkage between: 1) company performance, 2) S\&OP implementation, is difficult to prove. Especially given that there is a lack of a unifying framework for the measurement of tactical planning processes. Therefore, despite the broad publications on the topic of tactical planning, there is a lack of empirical scientific research exploring the issues of maturity using comparable quantitative methods [Noroozi and Wikner 2017], [Márcio et al. 2012]. The research gap and the interest of business in tactical planning is met by the support of consulting companies and suggestions for self-diagnosing questionnaires available on-line. The author of this paper assumes that evaluating the level of tactical planning maturity will enable: 1) diagnosing the effectiveness of supply chain functions, 2) determining the future development path for a given supply chain. Therefore, the research problem is the lack of a satisfying tool allowing to perform evaluation of tactical planning maturity in production companies, making it difficult to determine the future path of development for the supply chain.

The purposes of this paper are: 1) to provide review of literature referring to maturity models in supply chain with special focus on maturity models of Sales and Operation Planning; 2) based on literature research, to propose a model for evaluation of tactical planning maturity in supply chains of production companies; 3 ) to validate the construct of the model by using it to evaluate the maturity of tactical planning processes in two manufacturing companies; 4) to visualize the future path of supply chain development by indicating the level of tactical planning maturity in chosen companies before and after development of a Sales and Operational Planning process.

Therefore, this article contributes to scientific knowledge threefold, by providing: 1) a review of literature focused on the maturity models in supply chain and maturity models in tactical planning; 
2) a new framework for tactical planning maturity with assigned determinants and indicators; 3 ) insights into the future path of supply chain development for companies interested in Sales and Operational Planning implementation.

The paper is organized as follows: section 1. reviews the literature on: reasons of existence and construction scheme of maturity models, maturity models in supply chain, tactical planning process and maturity models of tactical planning. Section 2 describes the research methodology. Section 3 describes TPMM (Tactical Planning Maturity Model) proposed by the author of this paper. Section 4 describes the case studies in two companies; situations are observed before the development of a tactical planning process began, and after two years. Section 5 discusses the model and concludes with a summary of the research findings.

\section{LITERATURE RESEARCH}

\section{Maturity models}

Maturity models are perceived in literature as both means of assessment and a framework for improvement. The principal idea of the maturity grid is that it describes the typical behavior that could be perceived as a good practice. The behavior is codified on several levels that form a path of development from some initial state to some more advanced state. The concepts of maturity models are being applied to a number of business areas or operational functions. However, maturity approaches have their origins in quality management. Literature presents one of the first maturity models, Crosby's (1979), called Quality Management Maturity Grid (QMMG), where five levels of maturity for several aspects of quality are presented. Those levels are: uncertainty, awakening, enlightenment, wisdom, certainty.

Another model present in the literature is called: The Capability Maturity Model (CMM). This model takes a different approach from the quality grid; it identifies a cumulative set of "key process areas" (KPAs) which all need to be performed as the maturity level increases. This model was created for evaluation of the IT environment, however it is widely used to assess the maturity of other business operations. The CMM proposes five levels of maturity: initial, repeat- able, defined, managed and optimized. For each level, descriptions are provided and each key process area is organized into five sections called "common features", which are: commitment to perform, ability to perform, activities performed, measurement and analysis, verifying implementation. The common features specify the key practices and only when all of the practices are addressed is the goal of the key process area reached [Paulk 1993].

There are two types of models: stage and continuous. Stage type models require that a cumulative number of activities to be performed, where continuous type models are observed when different activities are scored at different levels [Mendes et al. 2016]. Additionally, maturity models might be divided into three groups: 1) maturity grids, 2) CMM-like models and 3) Likert-like questionnaires. The maturity grid models contain text description of each activity, and demonstrate a moderate complexity. The CMM family models have more formal and complex architecture, where each process area is organized by common features with specified key practices and a series of goals. Similarities can be noticed between maturity grids and Likert-scale questionnaires with anchor phrases. In this situation, Likert scale could be regarded as a maturity grid with only two extreme levels. Application of maturity levels could refer to self-assessment or an evaluation performed by an external auditor. There are common components which could be found at maturity models presented in the literature: 1) a number of levels (typically 3-6), 2) a descriptor for each level, 3) a generic description summary of the characteristic of each level as a whole, 4) a number of dimensions or "process areas", 5) a number of elements or activities for each process area, 6) a description of each activity as it might be performed at each maturity level [Fraser 2002].

\section{Supply Chain Maturity Models}

Scientific articles include a multitude of models concerning evaluation of the supply chain maturity. SCMM (Supply Chain Maturity Models) have functions that could be divided in two groups: 1) identification of the current state of a supply chain, 2) recommendations concerning improvements in the supply chain [Rutkowski 2016]. The process of creating SCMM can 
differ; it can use the Delphi method focusing on the statements of experts [Reyes and Giachetti 2010], the method of multi-criteria hierarchical analysis of decision problems (Analytic Hierarchy Process) [Mendes et al. 2016], or be formed based on the author's business experiences and literature research. Models are aimed to evaluate the entire organization concerning the supply chain or focus upon one of the aspects [Ocicka 2019], like for example assessment of the maturity of sustainable development in supply chains. The author of this paper is influenced by the work of Poirier, where five levels of supply chain development are proposed. This development is determined by the level of cooperation or integration. Poirier's model is constructed with cooperation of researchers whose work is presented in paragraph 1.1.4. Therefore, it is worth mentioning that researchers like Lapide and influencers from AMR Research who published on S\&OP maturity models also participated in the creation and review of Poirier's model [Poirier 2004]. On the first level of development, Poirier places functional integration of individual functions, on the second there is internal cross-functional integration. On the third level external network formation is observed, the fourth level is depicted as external value chain and the last most advance level implicates full network connectivity. Poirier assesses supply chain structure based on different categories; some are listed as maturity level qualities, others as excellence areas. Poirier notices that companies tend to present different internal levels of supply chain maturity, because some business units progress regardless of the rest of the company. Therefore, a firm can find itself with part of the organization spread across the entire evolutionary progression.

Poirier's model inspired many researchers, including Baraniecka, who studies companies in Poland. Barniecka's research encompasses 427 companies. Within the research, an incoherence in the responses regarding individual elements of the model is observed. This is caused by the same observation made previously by Poirier, where it was stated that companies tend to be present in different levels of supply chain maturity. Baraniecka concludes that researched companies are at the lowest maturity levels in terms of the supply chain management. A higher level of advancement is only noticed in terms of collaboration in strategic alliances. It is also concluded that companies localized in Poland demonstrate interest in the supply chain management concept and are open to new, dedicated solutions, and tools [Szymczak 2013].

\section{Tactical Planning}

In the literature, the tactical planning process is called S\&OP (Sales and Operations Planning). Wight's organization also introduced the name IBF (Integrated Business Planning). Tactical planning is a business process combining strategic plans with daily operational plans which enables companies to balance the demand side with the supply side [Grimson and Pyke 2007]. S\&OP can be perceived as a process aimed at creating the agreed operational plans that respond to the demand presented in the sales forecast.

Another approach, which is also adopted by the author of this article, is to perceive the tactical planning process as a technique to adapt the company's tasks to rapidly changing market realities [Olhager et al. 2001]. The literature describes the formula of a planning process consisting of monthly cycles within which data are collected and sequential meetings are held [Wallace 2008]. As part of the S\&OP process, individual functional plans (sales, marketing, product development, procurement and finance) are consolidated into a set of organized tactics that are transferred to the organization for the purpose of enforcing the agreed activities [Pedroso et al. 2016]. The S\&OP process promotes vertical and horizontal integration of processes and functions existing in the company's environment [Swink et al. 2007].

S\&OP typically follows a five-step process. First, the sales team meets to build a baseline demand forecast; this number captures what could be sold to customers and is called an unconstrained demand forecast. In this forecast, marketing plans such as advertising trade shows, promotions, new product introductions and product obsolescence are captured. The second step belongs to the operations team. They meet to gather information about inventory strategy, supply chain capacity and internal capacity, and build a constrained plan designed to meet the forecast requirements. In the third step, the S\&OP team meets to develop a final operating plan for the next period. Ideally, senior executives participate in the third step where the plan is re- 
viewed and approved for distribution. The fourth step is to distribute and implement the plan. The last step is to measure results and the effectiveness of the S\&OP process [Grimson and Pyke 2007].

\section{Sales and Operation Planning Maturity Models}

During the literature research, nine S\&OP maturity models were identified. Those models are presented in chronological sequence following specific categories in Table 1. Eight models treat S\&OP maturity and one model focuses on collaborative planning. Five articles include qualitative research and one provides quantitative studies. At the same time, three publications present no empirical research to test the proposed maturity model. It is important to mention that the majority of the articles are coming from the consulting world, and only four are scholarly publications.

As a second part, for the tactical planning maturity models review, the author investigates maturity levels and dimensions defining those levels. The first in the sequence, by year of publication, is Lapide, with the proposition of an S\&OP maturity model for companies which demonstrate a strategy to innovate and improve existing planning processes. The model is defined as a diagnostic tool designed to assess the "as is" situation and draft levels to which the company should evolve. Lapide specifies four stages in terms of meetings held, demand and supply plan alignments, and the enabling technologies used. The category describing meetings held starts from sporadic and informal meetings, through formal meetings, routinely scheduled with increasing attendance of participants, to eventdriven meetings scheduled when a change should be considered or when a supply-demand imbalance is detected.

The dimension of the model treating processes focuses on the evolution of alignment between demand and supply plans. On the lowest level, plans are disjointed. The second stage describes interfaced processes, then integrated plans with external collaboration with a limited number of suppliers and customers. The last ideal stage is characterized by demand and supply plans aligned internally and externally with the majority of supplier and customers. The third dimension refers to technology used in the S\&OP process. The lowest level starts from a multitude of spreadsheets and evolves as the process matures to stand-alone applications interfaced with integrated applications, still with external information manually entered into the process. The last stage represents the full set of integrated technologies, where external-facing collaborative software is integrated to internal demand-supply planning systems. Lapide highlights that the last stage of maturity - called 'ideal process' - is practically unachievable and it should be perceived as direction for the companies [Lapide 2005]. Empirical research on Lapide's model are not presented.

The second reviewed model is from the year 2007, created by Grimson and Pyke. This model is available in an academic article and presents a new framework for S\&OP integration. The authors aim to help managers understand the effectiveness of S\&OP within their companies and how to advance to the next stages of process maturity. The proposed framework consists of five stages specified in five dimensions and is based on review of the literature and on interviews in fifteen companies. The first three dimensions (meetings and collaboration, organization and measurements) are classified as business processes, the following two dimensions (information technology and S\&OP plan integration) are classified as information processes. The study concludes that business processes are enablers to S\&OP plan integration. Results are not conclusive concerning information technology; due to the sample size authors are only able to summarize that IT develops concurrently with plan integration. In this article authors conclude that there is no link between S\&OP maturity and firm size or its placement on the product-process matrix. Therefore, success and progress in S\&OP maturity depends highly on the management capabilities of the leaders and their capacity to develop business processes. Only in the fifth most mature level is information technology support in the decision making process assessed as indispensable [Grimson and Pyke 2007].

The third maturity model comes from a consulting company called AMR Research. AMR Research defines the journey for demand-driven S\&OP transformation. The model is composed of four stages, where sales priorities are balanced with priorities of operations. In the first stage, the organization is focused on development of an operational plan. In the second 
stage, focus shifts to demand and supply matching; the third is focused on reaching profitability. In the last, fourth stage, the organization is sensing demand, consciously processing trade-offs for demand shaping and is driving demand response in the existing business environment. This model includes a definition of metrics used at each of the four stages. Starting from order fill rate, asset utilization and inventory levels, and adding in the second stage of maturity, forecast error, inventory turns and functional costs. In the third stage, metrics visualizing demand error, customer service, working capital and total costs are proposed. The last stage of maturity is aimed at monitoring demand risk, customer service, cash flow, market share and profit [Cecere et al. 2009]. AMR Research presents positive results from S\&OP implementation; however, the sample and criteria of those studies remain unspecified.

The fourth maturity model was published in the Journal of Business Forecasting in 2010; this is a commercial journal and in this article also no academic research results are presented. A representative of Nextview Consulting, Tinker, proposes an S\&OP maturity model composed of five levels. The model starts from level 0 , where tactical planning is not present. At level 0 , discussions are focused on the current month, finances are not integrated and top management is not participating. Level 1 is called "basic" and it is a crossfunctional meeting where discussions are based on product families, and the planning horizon covers the longest lead-time items. On this level there is some financial involvement, KPIs are measured against targets and the executive team has awareness about the tactical planning effort. Level 2 is called "functional" and is supported by IT, the whole business is included in the process, KPIs have baselines and targets. Tinker mentions that on the second level participants are prepared, scenarios are discussed and decisions are made. Level 3 is called "maturing" and benefits from technology that supports decision making, the length of meetings is shortened, and representatives of finances actively participate in the decision making. Tinker also highlight that in the maturing S\&OP process, KPIs are challenged and there are actions set up in order to drive improvement in the areas pointed out by the indicators. In the third level, tactical planning is led by the executive team and there are specified rules for escalations. The highest level, level 4, is called "leading" and it is characterized by full integration with the budgeting process and the strategic plan. Accordingly, the planning horizon is extended and in companies with global businesses, S\&OP is led globally. On this level, the history of the effects of prior decisions are taken into consideration. Decision making is supported by IT solutions and captured in the workflow process [Tinker 2017].

The next model is proposed by the Aberdeen Group. Actually, this company published two articles on S\&OP maturity models. The model from 2011 describes and assesses the following dimensions of tactical planning: process, organization, knowledge, technology and measurement. In this article, the Aberdeen Group presents four case studies from various industries and presents pathways of those companies to implementing more mature S\&OP processes. A report provided by Aberdeen Group in 2015 explores the next steps to maturity of the S\&OP process. The next steps are understood as actions beyond matching demand and supply. The Group distinguishes three levels of maturity. The lowest level is called "laggards" and in this range Aberdeen classified 30\% of researched companies. At the second level, the Group classified $50 \%$ of companies, called "industry average". Twenty percent of companies are placed at the most mature level, called "best-in-class". In the presented results, companies with more mature S\&OP processes are more concerned with enhancing their value to customers and grow relationships. Priorities for less mature businesses are more contained within the supply chain organization and are involved with improving the basic S\&OP process. According to Aberdeen, companies with less developed tactical planning focus on integrating S\&OP with the financial planning and budgeting process. This step is often characterized as moving to "integrated business planning" and this point distinguishes the moment where S\&OP moves beyond demand/supply matching.

The second academic publication referring to tactical planning maturity models was published by the Aberdeen Group in 2013. This publication focused on structural elements of coordination mechanisms in the collaborative planning process. Authors identify nine structural elements and propose their assessment using 
the scheme of five levels: initial, repeatable, defined, managed and optimized. The five levels present for the assessment are sourced from the CMM maturity model described in paragraph 1.1.1. The mine structural elements on which the assessment is based are: 1) number of decision makers, 2) collaboration level, 3) interdependence relationship nature, 4) interdependence relationship type, 5) number of coordination mechanisms, 6) information exchanged, 7) information processing, 8) decision sequence characteristics and 9) stopping criteria. Collaborative planning is perceived and defined as a decision making process for aligning plans of individual supply chains. The goal of such a process is coordination of individual plans. Identification and categorization of interdependencies is managed via different coordination processes [Cuenca et al. 2013]. The authors tested the proposed model on one company using the case study method and the sequential three iterations. The improvements in the assessed areas are reported.

The eighth article is based on the Grimson and Pyke framework [Grimson and Pyke 2007]. In the article, published in 2015, Goh and Eldridge [2015] investigate implementation and performance benefits of the S\&OP process in companies located in the Asia-Pacific region. The authors of the article conducted research using the case study method in two companies. In both cases, the authors present significant improvements in supply chain performance. The subjects that are particularly interesting for the researchers are: new product introduction and supplier integration in the S\&OP process.

The ninth example of research is the fourth from an academic source and the third where the assessment is based on the Grimson and Pyke work from the year 2007. In the article from 2017, Naslund and Williamson use the model proposed by Grimson and Pyke to assess the maturity of S\&OP at six paper manufacturers located in the United States. In the article there are no factual assessments or comparison of the maturity level in the researched companies. Furthermore, the authors speculate on the benefits of S\&OP implementation. The following benefits are listed, potentially leading to gaining competitive advantage: development of core competency in forecasting and breaking down silo walls [Naslund and Williamson 2017].

Table 1. Selected sales and operation planning maturity models

\begin{tabular}{|c|c|c|c|c|}
\hline $\begin{array}{l}\text { Source in the literature in the } \\
\text { sequence of appearance }\end{array}$ & Model source & $\begin{array}{c}\text { Model } \\
\text { business scope }\end{array}$ & $\begin{array}{l}\text { Empirical } \\
\text { research on the } \\
\text { model }\end{array}$ & $\begin{array}{l}\text { Scholarly } \\
\text { or consulting } \\
\text { research }\end{array}$ \\
\hline [Lapide 2005] & own model & $\mathrm{S} \& \mathrm{OP}$ & not available & consulting \\
\hline [Grimson and Pyke 2007] & $\begin{array}{l}\text { own model- } \\
\text { model Grimson and Pyke [2007] }\end{array}$ & $\mathrm{S} \& \mathrm{OP}$ & $\begin{array}{l}\text { yes, interviews in } \\
15 \text { companies }\end{array}$ & academic \\
\hline [AMR Research 2009] & own model & S\&OP & not available & consulting \\
\hline [Tinker 2010] & own model & S\&OP & not available & consulting \\
\hline [Aberdeen Group 2011] & own model & $\mathrm{S} \& \mathrm{OP}$ & $\begin{array}{l}\text { yes, case study, } \\
4 \text { companies }\end{array}$ & consulting \\
\hline [Cuenca et al. 2013] & $\begin{array}{l}\text { own model called SECM } \\
\text { (Structural elements } \\
\text { of coordination mechanisms) }\end{array}$ & $\begin{array}{l}\text { collaborative } \\
\text { planning process } \\
(\mathrm{CP})\end{array}$ & yes, 1 company & academic \\
\hline [Aberdeen Group 2015] & own model & S\&OP & $\begin{array}{c}\text { yes, } 167 \text { compa- } \\
\text { nies }\end{array}$ & consulting \\
\hline [Goh and Eldridge 2015] & model Grimson and Pyke [2007] & S\&OP & $\begin{array}{l}\text { yes, case study, } 2 \\
\text { companies }\end{array}$ & academic \\
\hline [Naslund and Williamson 2017] & model Grimson and Pyke [2007] & S\&OP & $\begin{array}{l}\text { yes, interviews } \\
\text { in } 6 \text { companies }\end{array}$ & academic \\
\hline
\end{tabular}

Source: Author's own elaboration. 


\section{RESEARCH METHODOLOGY}

The first step in the research is the literature review. Literature research is conducted in order to draft a model called in the paper TPMM (Tactical Planning Maturity Model). A literature review was re-launched during the second case study when the need arose to update the original construct. During the second case study it was discovered that production schedules were being changed by shop floor workers, because daily production schedules were overpassing daily production capacity. Due to this discovery, a literature review was re-launched and level 1 of TPMM was added, shown visualized in Table 2. Analysis demonstrating comparison of selected models presented in paragraphs 1.1.2 and 1.1.4 was based on research in the: 1) EBSCO database, 2) www.deepdyve.com multi-site search engine using constructs like: the 'maturity in supply chain', 'maturity in tactical planning' and 'maturity in S\&OP' and 3) business publications. In a review of maturity models - both supply chain maturity models and sales and operation planning maturity models - the author identifies the following as important: model creation process, business scope and the presence of empirical research.

The second step of the research consisted of choosing a case study method to verify the adequacy of a TPMM in two manufacturing companies operating in Poland. The case study method focuses on participant observation and data gathering. The described companies were chosen because they both operate in an international, corporate, manufacturing environment with complex supply chains and the management has declared a strategy to improve the tactical planning process in order to positively impact company performance. Observations were conducted in the company described as company A in years 2012-2014, and in company B in years 2015-2017. Observations were spread over the years after a transformation toward a mature sales and operation planning process was launched, because the goal of the research was to empirically confirm the sequence of the supply chain development, tactical planning transformation path and performance consequences.

\section{DESCRIPTION OF PROPOSED MODEL}

The scope of the Tactical Planning Maturity Model (TPMM) encompasses the concept of supply chain integration levels inspired by work of Poirier and tactical planning stages listed by Cecere in the book "Supply chain metrics that matter" [Cecere et al. 2014]. In the TPMM construct, five stages present in Cecere's publication fit into the levels of supply chain integration present in Poirier's work. On the basis of case study research, the author of this article modified the five stages of evolution from Cecere's work by adding one stage, where planning is determined by production capacity. In the next step, the author of this article deepens the definition of each stage level by operationalizing conceptual descriptions and implementing measurements with specified indicators.

Table 2. Visualization of research methodology

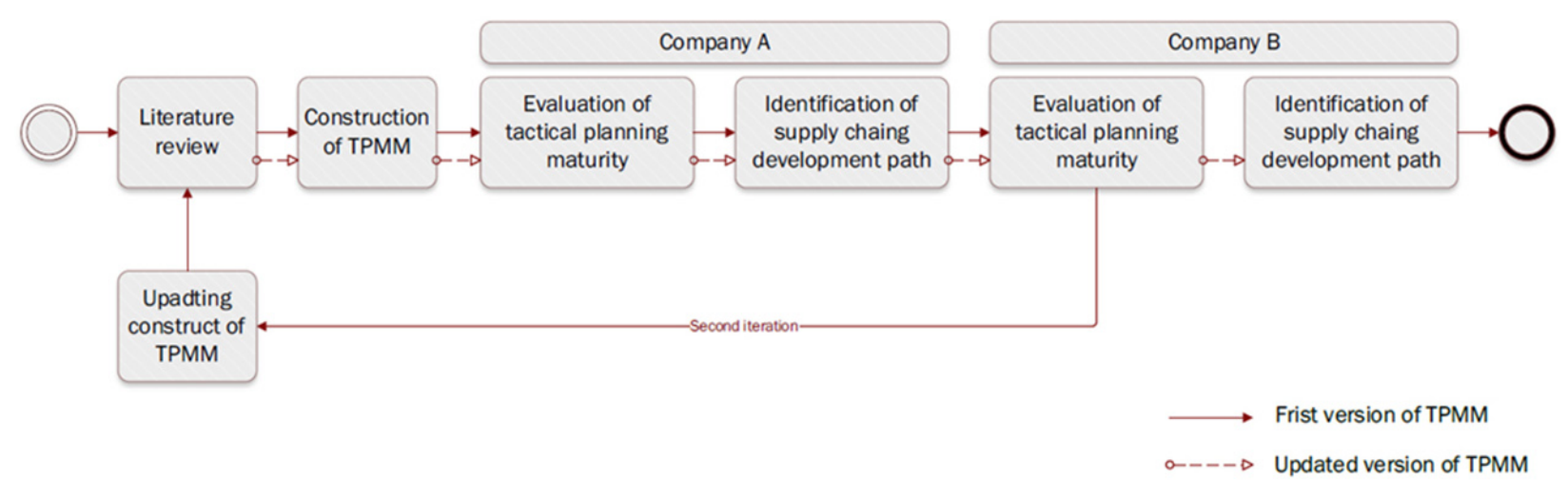

Source: Author's own elaboration. 
In TPMM, the specific level of supply chain maturity from Poirier's work determines the possibilities of the tactical plan [Poirier 2004]. Moreover, supply chain integration level determines the performance of an organization and potential improvements of organizational effectiveness and efficiency. Those variables are visualized in Table 3 . The model refers to the maturity models type stage, where cumulative activities need to be performed in order to progress through levels. For the assessment purposes, the author of TPMM makes the assumption that if, in a given company, the tactical planning maturity level is managed by the proposed indicator, then the information provided is accepted and treated as representative for the whole company. This assumption refers to the previous inconsistences in research reported in paragraph 1.1.2 by Poirier and Baraniecka. For the TPMM construct it is conclusive to state that if part of a company is at a given tactical planning maturity level, then the knowledge about the steps to follow in order to develop the tactical plan- ning is present in the company. Therefore, it is a top management decision to spread the knowledge and best practices already present in the company over other divisions or business units.

In the model, similarities can be noticed between grid and Likert-scale questionnaires with anchor phrases with only two extreme levels. In the case of the TPMM extreme levels of the scale describe the existence or lack of a proposed tactical planning indicator. The author suggests further developing the model by adding information about measurement results. Results could be analyzed and categorized following the nomenclature presented, for example, by the Aberdeen Group: 1) laggard, 2) industry average, 3) best-inclass. This development of the TPMM is visualized in Table 4. Please note that in the proposal of the TPMM matrix, percentages are present just for visualization purposes. Application of TPMM and assessment of tactical planning maturity can be performed by a person from the company or an external auditor.

Table 3. TPMM variables

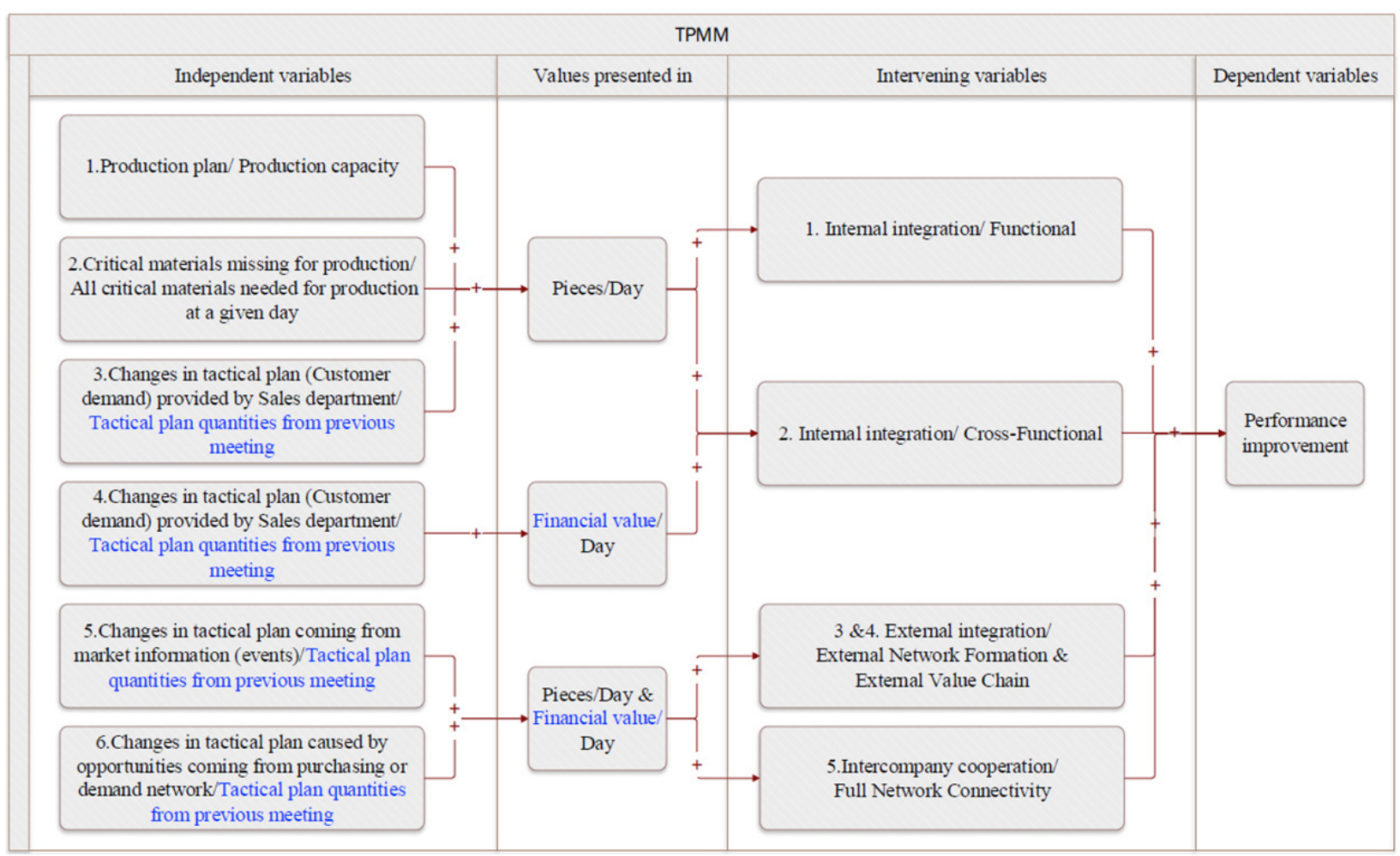

Source: Author's own elaboration. 
Szczakowska. D. (2021). Evaluation of tactical planning maturity in supply chains of manufacturing companies. Acta Sci. Pol. Oeconomia 20 (2), 79-93, doi: 10.22630/ASPE.2021.20.2.18

Table 4. Proposal of the TPMM Matrix (percentages are present just for visualization purposes)

\begin{tabular}{|c|c|c|c|c|c|c|}
\hline Indicators of TPMM & $\begin{array}{l}\text { Values } \\
\text { presented } \\
\text { in... }\end{array}$ & $\begin{array}{l}\text { Presence } \\
\text { of measure } \\
\text { in ... }\end{array}$ & $\begin{array}{l}\text { Presence } \\
\text { of measure } \\
\text { in ... }\end{array}$ & $\begin{array}{l}\text { Laggard } \\
\quad(\%)\end{array}$ & $\begin{array}{l}\text { Industry } \\
\text { average } \\
(\%)\end{array}$ & $\begin{array}{c}\text { Best- } \\
\text {-in-class } \\
(\%)\end{array}$ \\
\hline Production plan/Production capacity & pieces/day & yes or no & yes or no & $70-80$ & $80-85$ & $85-95$ \\
\hline $\begin{array}{l}\text { Critical materials missing for production/All critical } \\
\text { materials needed for production at a given day }\end{array}$ & pieces/day & yes or no & yes or no & $3-4$ & $1-2$ & $0,5-0,8$ \\
\hline $\begin{array}{l}\text { Changes in tactical plan (Customer demand) } \\
\text { provided by Sales department/Tactical plan } \\
\text { quantities from previous meeting }\end{array}$ & pieces/day & yes or no & yes or no & $10-20$ & $5-10$ & $0-5$ \\
\hline $\begin{array}{l}\text { Changes in tactical plan (Customer demand) pro- } \\
\text { vided by Sales department/Tactical plan quantities } \\
\text { from previous meeting }\end{array}$ & $\begin{array}{c}\text { financial } \\
\text { value/day }\end{array}$ & yes or no & yes or no & $10-20$ & $5-10$ & $0-5$ \\
\hline $\begin{array}{l}\text { Changes in tactical plan coming from market } \\
\text { information (events)/Tactical plan quantities from } \\
\text { previous meeting }\end{array}$ & $\begin{array}{l}\text { pieces/day } \\
\text { and } \\
\text { financial } \\
\text { value/day }\end{array}$ & yes or no & yes or no & $0-5$ & $5-10$ & $10-20$ \\
\hline $\begin{array}{l}\text { Changes in tactical plan caused by opportunities } \\
\text { coming from purchasing or demand network/ } \\
\text { /Tactical plan quantities from previous meeting }\end{array}$ & $\begin{array}{l}\text { pieces/day } \\
\text { and } \\
\text { financial } \\
\text { value/day }\end{array}$ & yes or no & yes or no & $0-5$ & $5-10$ & $10-20$ \\
\hline
\end{tabular}

Source: Author's own elaboration

\section{CASE STUDIES RESULTS}

The first step of the observation consists of evaluating the tactical planning process maturity. For company A it is level 3, where changes in the tactical plan are pro- vided by the sales department and are calculated versus tactical plan quantities from a previous meeting. For company B it is level 1, where the production plan is compared to production capacity. In the second step of the observation, the path of supply chain develop-

Table 5. Comparison of observations, company A

\begin{tabular}{|c|c|c|c|}
\hline Indicators of TPMM & $\begin{array}{l}\text { Values } \\
\text { presented in }\end{array}$ & $\begin{array}{c}\text { Presence } \\
\text { of } \\
\text { measure } \\
\text { in } 2012\end{array}$ & $\begin{array}{c}\text { Presence } \\
\text { of } \\
\text { measure } \\
\text { in } 2014\end{array}$ \\
\hline Production plan/Production capacity & pieces/day & yes & yes \\
\hline $\begin{array}{l}\text { Critical materials missing for production/All critical materials needed for production } \\
\text { at a given day }\end{array}$ & pieces/day & yes & yes \\
\hline $\begin{array}{l}\text { Changes in tactical plan (Customer demand) provided by Sales department/Tactical plan } \\
\text { quantities from previous meeting }\end{array}$ & pieces/day & yes & yes \\
\hline $\begin{array}{l}\text { Changes in tactical plan (Customer demand) provided by Sales department/Tactical plan } \\
\text { quantities from previous meeting }\end{array}$ & $\begin{array}{l}\text { financial value/ } \\
\text { /day }\end{array}$ & no & yes \\
\hline $\begin{array}{l}\text { Changes in tactical plan coming from market information (events)/Tactical plan quanti- } \\
\text { ties from previous meeting }\end{array}$ & $\begin{array}{c}\text { pieces/day } \\
\text { and financial } \\
\text { value/day }\end{array}$ & no & no \\
\hline $\begin{array}{l}\text { Changes in tactical plan caused by opportunities coming from purchasing or demand } \\
\text { network/Tactical plan quantities from previous meeting }\end{array}$ & $\begin{array}{c}\text { pieces/day } \\
\text { and financial } \\
\text { value/day }\end{array}$ & no & no \\
\hline
\end{tabular}

Source: Author's own elaboration. 
Table 6. Comparison of observations, company B

\begin{tabular}{|c|c|c|c|}
\hline Indicators of TPMM & $\begin{array}{l}\text { Values } \\
\text { presented in }\end{array}$ & $\begin{array}{l}\text { Presence } \\
\text { of } \\
\text { measure } \\
\text { in } 2015\end{array}$ & $\begin{array}{l}\text { Presence } \\
\text { of } \\
\text { measure } \\
\text { in } 2017\end{array}$ \\
\hline Production plan/Production capacity & pieces/day & yes & yes \\
\hline $\begin{array}{l}\text { Critical materials missing for production/ } \\
\text { All critical materials needed for production at a given day }\end{array}$ & pieces/day & no & yes \\
\hline $\begin{array}{l}\text { Changes in tactical plan (Customer demand) provided by Sales department/Tactical plan } \\
\text { quantities from previous meeting }\end{array}$ & pieces/day & no & yes \\
\hline $\begin{array}{l}\text { Changes in tactical plan (Customer demand) provided by Sales department/Tactical plan } \\
\text { quantities from previous meeting }\end{array}$ & $\begin{array}{l}\text { financial value/ } \\
\text { /day }\end{array}$ & no & no \\
\hline $\begin{array}{l}\text { Changes in tactical plan coming from market information (events)/Tactical plan } \\
\text { quantities from previous meeting }\end{array}$ & $\begin{array}{l}\text { pieces/day } \\
\text { and financial } \\
\text { value/day }\end{array}$ & no & no \\
\hline $\begin{array}{l}\text { Changes in tactical plan caused by opportunities coming from purchasing or demand } \\
\text { network/Tactical plan quantities from previous meeting }\end{array}$ & $\begin{array}{l}\text { pieces/day } \\
\text { and financial } \\
\text { value/day }\end{array}$ & no & no \\
\hline
\end{tabular}

Source: Author's own elaboration.

ment following the tactical planning levels and supply chain integration sequence is confirmed. In company A, top management voices a need to present and supervise changes in the tactical plan provided by the sales department, adding changes in financial values, which led the company to level 4 of TPMM. And in company $\mathrm{B}$, critical materials missing for production are supervised, followed by management of changes in the tactical plan provided by the sales department. Those steps led company B to level 3 of TPMM. Especially, in the example of company B, the author observed sequential steps of tactical planning maturity. Once capacity planning capability is improved, the company required improvements and monitoring of the availability of critical components for production processes. As a next step, reliability and changes to the tactical plan were managed and questioned.

\section{CONCLUSIONS}

The proposed framework, called TPMM (Tactical Planning Maturity Model), is focused on integration of tactical plans presented in a production company. Integration of tactical plans is also presented as one of five dimensions in the Grimson and Pyke maturity mo- del. As discussed in paragraph 1.1.4., the Grimson and Pyke maturity model is the most used S\&OP maturity model by academics. The author of this paper focuses on integration of plans and expands this dimension to the maturity framework. The author believes that in the Grimson and Pyke article, integration of plans was not explored sufficiently and that the concept of plan integration was limited to information about sales, supply plans and the way those plans are interfaced. Grimson and Pyke categorized integration of plans to the information technology scope, not to the business responsibility. The author of this paper shows that this is an error and inconsistency in the Grimson and Pyke article, as the subject of plan integration should not be limited to the matter of technical interfaces. At the same time, in the Grimson and Pyke article it is possible to find a statement highlighting the importance of plan integration: "S\&OP plan integration measures how effective a company builds its sales plans and operations plans, and how well the plans interface. Such integration is the goal of the meetings, measurements, organizations changes and information technology" [Grimson and Pyke 2007].

The other model used by representatives of the academic world is called SECM (Structural Elements 
of Coordination Mechanisms). This model defines and assesses the structural elements of coordination mechanisms in the collaborative planning process. The authors of SECM focus on business processes and collaboration, but they do not explore the dimension of plans included in the tactical planning. Similar to the authors of SECM, the Grimson and Pyke framework includes assessment of business processes enabling tactical planning. In those processes Grimson and Pyke included three dimensions: meetings and collaboration, organization and measurements. The author of this publication assumes that companies voicing a willingness to participate in the tactical planning maturity assessment are aware of the importance of organized exchanges between different functions. Therefore, the observations presented in the paper are limited to the companies where S\&OP meetings are already held. In the TPMM, dimensions of integration are sequenced based on supply chain integration levels and most influenced by work presented by Poirier [Poirier 2004].

Supply chain integration, specifically external integration with suppliers is proven to have an amplifying impact on internal S\&OP. Incremental performance gains caused by external integration are visualized by Goh and Eldridge, authors who in 2015 published a second academic article using the Grimson and Pyke framework [Goh and Eldridge 2015]. Researchers are using the Grimson and Pyke maturity model and are proving performance gains of organizations that were assessed via the model. However, the author of this article is noting a lack of benchmarking possibilities due to the lack of standardized measurements. This conclusion is clearly visible in the third academic article where the Grimson and Pyke maturity model was used, in 2017, by Naslund and Williamson. In that article, no quantitative results from interviews were listed. The authors state: "We suggest that firms implementing S\&OP processes begin reaping positive results immediately and that as firms refine S\&OP processes, benefits will continue to increase. Yes, we are speculating, but the positive if qualitative comments from our study participants support our assertion" [Naslund and Williamson 2017].

In the opposition to the speculations based on existing maturity models of tactical planning, the TPMM framework proposes assessment via questions based on measurements. Measurements prove and reveal if the declared plan is indeed integrated in the company and the measured result could provide insights into the level of management for the area. Values potentially visualized via those indicators could reveal real lost opportunities and issues within operations. Company management could build action plans based on gaps in operations visible thanks to indicators. Therefore, the TPMM framework could be used to compare performance in a given part of operations and could be benchmarked between different companies. Due to transparency in gaps, a development path for the supply chain could be created. The ultimate purpose of plans presented in the TPМM is to use that data to create 'what-if' scenarios in the organization. Discussions on 'what-if' scenarios trigger trade-off decisions and as a result, the "potential of a given entity against the background of future predictions" [Komorowski 2015] could be used.

"What-if" scenarios are often supported by information technology and advanced planning applications. Some authors writing about S\&OP posit that support of information technology is crucial and indispensable in order to progress with maturity of tactical planning. The author of this publication decided to limit the assessment model to the evaluation of plan integration regardless of the technology used. This assumption was based on research results provided by Grimson and Pyke, where interviews do not provide causality of conjecture that information processes are enablers of S\&OP maturity [Grimson and Pyke 2007].

In the next steps, potential results revealed via TPMM framework and plan measurements could create benchmark for other companies interested in maturity assessment of their tactical planning. Creation of TPMM is influenced by Cecere and the book "Supply chain metrics that matter"; this source of inspiration is described in detail in paragraph 3. In the book, Cecere suggests an additional stage of S\&OP evolution [Cecere et al. 2014], to follow the last level present in the Grimson and Pyke framework. Cecere states that the goal of the fifth stage is to orchestrate business through market-driven value networks and usage of opportunities from both the purchasing and demand sides. In the Grimson and Pyke framework, 
the maturity ends on level 4 , if using the numeric and nomenclature from the Cecere publication. Therefore, in the Grimson and Pyke framework, assessment of tactical planning maturity finishes on external integration of supply chain and the last level of supply chain integration - called 'inter-company cooperation' - is not present.

In the case studies presented in paragraph 4 , the author is not allowed to publicly share the results gathered via the indicators. As consequence, assessments in the case studies are limited to Likert-scale questionnaires with anchor phrases with only two extreme levels (Is the measurement present in a given year? With the possibility of answer: yes or no). Therefore, the efficiency assessments in Tables 5 and 6 are limited to the confirmation that indicators assigned to each level of TPMM are being implemented in the company and that indicators are being monitored by management. However, it is confirmed that results from the measurements are used by both companies' top management to create action plans and advance their companies' supply chains. The advancement is visible in the progress made by both companies in their plan integration and in the progress in tactical planning maturity.

The question might be raised as to whether progress was made due to the initiation of a tactical planning program in the researched companies. As other researchers on S\&OP have noticed, it is difficult to prove a direct and singular influence of a tactical planning program on improvement in company performance. However, a tactical planning program is one of only a few initiatives where participants from various functions in the organization gather in one meeting with the common purpose of company performance improvement and where engagement and guidance of the company leader is required at stable intervals. The author of this paper suggests that academic quantitative research should be launched in order to bridge the gap between companies' need for guidance in the area of tactical planning and suggestions provided by consulting companies. The need for guidance and the fact that this need mainly being addressed by consulting companies is proven by the number of S\&OP maturity models and publications on the subject discussed in paragraph 1.1.4 of the literature research.
The TPMM is a ready-to-use tool where the line to supply chain maturity is clearly drafted and where results could be compared between production companies. In the case studies carried out, evolution of the tactical planning process following the subsequent levels of maturity is observed. The first four levels of TPMM are confirmed. Unfortunately, the remaining two levels of tactical planning maturity and their impact on the supply chain development were not noted during the observations.

It was additionally observed that evaluating tactical planning maturity allows to distinguish the future path of development for a particular supply chain. Further quantitative studies are required for testing the accuracy of the proposed model. In paragraph 3 , Table 4, the author suggests to categorize each TPMM level advancement based on the benchmarked results from other production companies. This comparison requires further quantitative studies and sharing of measurement results with public. If this is possible, case studies presented in the Likert-scale will not be limited to two extreme levels, and to simple answers as to whether the measurement is present or not. The scale could be increased and adjusted following the indicator results reported by the companies. In Table 4 the author presents a matrix composed of 6 levels of tactical planning and 3 levels based on nomenclature used by the Aberdeen Group. Potentially, qualitative studies could be undertaken in order to understand factors enabling the increase in maturity of tactical planning in the supply chains of manufacturing companies.

\section{REFERENCES}

Aberdeen, G. (2011). Executive Sales and Operations Planning Maturity Levels and Key So-lution Criterion. Retrieved from https://archive.sap.com/kmuuid2/ c034c211-3032-2f10-3aa6-bf48c6b326f3/Executive\%2 0Sales\%20and\%20Operations\%20Planning\%20Matur ity $\% 20$ Levels $\% 20$ and $\% 20 \mathrm{Key} \% 20$ Solution $\% 20$ Criteri on.pdf [accessed 01.06.2019].

Cecere, L., Barrett, J., Mooraj, H. (2009). Sales and Operations Planning: Transformation from Tradition. AMR Research, Inc. Retrieved from https://docplayer. net/32332894-Sales-and-operations-planning-transformation-from-tradition.html. Available: https://docplay- 
er.net/32332894-Sales-and-operations-planning-transformation-from-tradition.html [accessed 09.06.2020].

Cecere, L.M. (2014). Supply chain metrics that matter. John Wiley \& Sons, New Jersey.

Cuenca, L., Boza, A., Alemany, M.M.E., Trienekens, J.J.M. (2013). Structural elements of coordination mechanisms in collaborative planning processes and their assessment through maturity models: Application to a ceramic tile company. Computers in In-dustry 64, 898-911.

Fraser P, M. J., Gregory M. (2002). The use of maturity models/Grids as a tool in assessing product development capability. Conference: Engineering Management Conference, IEEE International, Cambridge. Retrieved from https://www.researchgate.net/publication/3970465_ The_Use_of_Maturity_ModelsGrids_as_a_Tool_in Assessing_Product_Development_Capability [accessed 01.09.2019].

Goh, S.H., Eldridge, S. (2015). New product introduction and supplier integration in sales and operations planning. International Journal of Physical Distribution \& Logistics Management 45, 861-886.

Grimson, A.J., Pyke, D.F. (2007). Sales and operations planning: an exploratory study and framework. The International Journal of Logistics Management 18, 322-346.

Komorowski, J. (2015). Zarys budżetowania przedsiębiorstwa. SGH, Warszawa.

Lapide, L. (2005). Sales and Operations Planning Part Iii: A Diagnostic Model. Journal of Business Forecasting 24, 13-16.

Márcio, A., Scavarda, L.F., Fernandez, N.S., Scavarda, A.J. (2012). Sales and operations planning: a research synthesis. International Journal of Production Economics 138(1), 1-13.

Mendes, P., Leal, J.E., Thomé, A.M.T. (2016). A maturity model for demand-driven supply chains in the consumer product goods industry. International Journal of Production Economics, 179, 153-165.

Naslund, D.,Williamson, S. (2017). Sales and operations planning - A potential strategic tool for the US paper industry. Journal of International Business Disciplines $12,1-15$.

Noroozi, S., Wikner, J. (2017). Sales and operations planning in the process industry: A literature review. International Journal of Production Economics, 188, 139-155.
Ocicka, B. (2019). Rola zakupów w działalności przedsiębiorstw. Wydawnictwo Naukowe PWN, Warszawa.

Olhager, J., Rudberg, M., Wikner, J. (2001). Long-term capacity management: Linking the perspectives from manufacturing strategy and sales and operations planning. International Journal of Production Economics 69, 215-225.

Paulk, M.C. (1993). Comparing ISO 9001 and the Capability Maturity Model for Software. Software Quality Journal 2, 245-256.

Pedroso, C.B., Da Silva, A.L., Tate, W.L. (2016). Sales and Operations Planning (S\&OP): Insights from a multicase study of Brazilian Organizations. International Journal of Production Economics 182, 213-229.

Poirier, C.C. (2004). Using Models to Improve the Supply Chain. ST. Lucie Press, Boca Raton.

Reyes, H.G., Giachetti, R. (2010). Using experts to develop a supply chain maturity model in Mexico. Supply Chain Management 15, 415-424.

Rutkowski, K. (2016). Zarządzanie łańcuchem dostaw w XXI wieku: w poszukiwaniu nowych źródeł przewagi konkurencyjnej. Oficyna Wydawnicza SGH, Warszawa.

Swaim, J.A., Maloni, M., Bower, P., Mello, J. (2016). Antecedents to effective sales and operations planning. Industrial Management \& Data Systems 116, 1279-1294.

Swink, M., Narasimhan, R., Wang, C. (2007). Managing beyond the factory walls: Effects of four types of strategic integration on manufacturing plant performance. Journal of Operations Management 25, 148-164.

Szymczak, M. (2013). Managing Towards Supply Chain Maturity. Palgrave Macmillan, London.

Tinker, E.J. (2010). Revitalize Your S\&OP. Journal of Business Forecasting 29(3), 5-12. Retrieved from http:// Www.nexviewconsulting.com/perspectives/Revitalize_ Your_S\&OP_IBF.pdf [accessed 01.05.2020].

Tinker, E.J. (2017). The Executive Guide to S\&OP Implementation. Nexview Consulting, LLC, Houston. Retrieved from http://www.nexviewconsulting.com/perspectives/eBooks/sop-impl/SOP_Implementation_Success-ebook.pdf [accessed 01.12.2020].

Wallace, T.F. (2008). Sales \& Operations Planning. T.F.Wallace \& Comapny, USA. 


\section{OCENA DOJRZAŁOŚCI PLANOWANIA TAKTYCZNEGO W ŁAŃCUCHACH DOSTAW FIRM PRODUKCYJNYCH}

\section{STRESZCZENIE}

Artykuł ma na celu przedstawienie propozycji oraz przeprowadzenie weryfikacji modelu umożliwiającego dokonanie oceny dojrzałości taktycznego planowania w łańcuchach dostaw firm produkcyjnych. Autor prezentuje model zwany w języku angielskim Tactical Planning Maturity Model (TPMM). Model został stworzony na podstawie badań literatury tematu, obserwacji uczestniczącej oraz gromadzenia danych przeprowadzone $\mathrm{w}$ dwóch przedsiębiorstwach. Zaproponowana struktura modelu łączy wiedzę na temat integracji łańcucha dostaw oraz niezbędnych etapów prowadzących do osiągnięcia biegłości w planowaniu sprzedaży i operacji. W drugim kroku wybrana została metoda badania studium przypadku, której zadaniem była weryfikacja modelu w dwóch przedsiębiorstwach produkcyjnych operujących na terenie centralnej Polski. Rezultaty przeprowadzonych badań ukazują TPMM jako narzędzie, za pomocą którego możliwa jest diagnoza poziomu dojrzałości łańcucha dostaw. Dodatkowo model umożliwia dokonanie porównania poziomów dojrzałości pomiędzy przedsiębiorstwami produkcyjnymi. Artykuł wzmacnia połączenie między praktykami a literaturą akademicką poprzez wskazanie empirycznych dowodów na korzyści płynące z zastosowania modelu we wspieraniu rozwoju łańcucha dostaw. Badaniu zostały poddane jedynie dwa przedsiębiorstwa, dlatego rezultaty zawarte w artykule nie mogą być uogólniane dla wszystkich przedsiębiorstw produkcyjnych pragnących zrozumieć kompleksowość oraz dojrzałość łańcuchów dostaw. Dodatkowo przebadane przedsiębiorstwa osiągnęły jedynie czwarty poziom dojrzałości, pozostałe dwa poziomy przedstawione w modelu nie zostały zaobserwowane. Niezbędne jest przeprowadzenie dalszych ilościowych badań w celu kontynuowania testu spójności modelu. Ponadto, przeprowadzenie jakościowych badań umożliwiłoby wskazanie czynników wspierających wzrost dojrzałości w procesach taktycznego planowania w łańcuchach dostaw przedsiębiorstw produkcyjnych.

Słowa kluczowe: model dojrzałości planowania taktycznego, model dojrzałości S\&OP, model dojrzałości planowania sprzedaży i operacji, rozwój łańcucha dostaw, model dojrzałości łańcucha dostaw 